\title{
Foreign language teachers' preparing for a mobile educational future
}

\author{
T. M. Kolodko
}

Taras Shevchenko National University of Kyiv, Ukraine

Corresponding author. E-mail: tnkolodko@gmail.com

Paper received 10.05.19; Accepted for publication 21.05.19.

\section{https://doi.org/10.31174/SEND-PP2019-198VII80-05}

\begin{abstract}
Theoretical and practical fundamentals of foreign language teachers' preparing for a mobile educational future are substantiated in the study. Benefits, limitations and risks of using mobile applications in the process of teaching are identified. The scientists' outlooks on the given issue are analyzed. The models for future foreign language teacher training in new technologies Content and Language Integrated Learning (CLIL) and Technological Pedagogical Content Knowledge (TPCK) are outlined. Some recommendations for using mobile technologies in education are highlighted.
\end{abstract}

Keywords: future foreign language teachers, mobile educational future, $21^{\text {st }}$ century skills, digital training, mobile devices.

Introduction. Global integration processes can't bypass effectiveness of the use of mobile technologies for teaching and learning. In the developing world, there's a pressing need to find the most accessible digital interface, which is often a mobile phone screen, but may sometimes be a screen on a laptop or other device.

Mobile devices are increasingly part of a multiscreen system. This system comprises mobile devices like smartphones and tablets; borderline mobile/portable devices like notebooks and laptops; and fixed devices ranging from desktop computers to television screens and interactive whiteboards. It's up to each of us as individuals to work out the right niche for mobile technologies in the stream of information and communication flowing across and between our multiple screens.

It's become clear that mobile technologies are embedded in complex tasks of use. Successful projects, those that transform teaching and learning, develop $21^{\text {st }}$ century skills, and bring education often at scale to understand everybody - must work within these tasks by building partnerships with international, national and local organizations, institutions and companies, as well as political, social and educational leaders.

The future direction of Internet development leads beyond the Internet itself, and it's important that mobile devices truly come into their lives as they challenge our sense of space and place. Mobile tools permit the web and the world to intersect, a phenomenon, which has been dubbed 'Web Meets World' [9].

Brief review of publications on the subject. The analysis of psychological and pedagogical literature testifies to the continuous scientific search for the solutions to this problem, and is clearly elucidated in the works of such Ukrainian and Foreign scholars as P. Serdyukov, T. Kolodko, L. Kotlyar, O. Safonova, Ye. Polat, G. Dudeney, J. Higgins, A. Lund, M. Pegrum, V. Rotwell, R. Sussex, and many others. Today, there is no doubts that the status and prospects of mobile learning are determinants of the progress.

Thus, the purpose of the article is to examine theoretical and practical fundamentals of mobile learning.

Presenting main material. As mobile technologies flourish around us, it's important to pause and ask ourselves: why should/shouldn't we be using these tools in education? What do they achieve? Whose interests do they serve? These questions go to the heart of what we think education is, or could be. Is this picture familiar?
Some students sit silently in fixed rows, hands raised, waiting to be chosen to respond to a question from the teacher. Others sit with their heads down, reading set texts and penning their answers, as they memorize facts for recalling in high-standard tests. Most of us know this stereotype. Most of us have experienced some version of it at some time. But this $20^{\text {th }}$ century model of education, with its genesis in the late $19^{\text {th }}$ century, is outdated, say critics $[1 ; 6]$.

So, there's also a pressing need for teacher training about mobile technologies. It's estimated that up to half of all teachers lack adequate ICT training. Thus, the need for teacher training about mobile tools is the first question to solve. However, it's not just a question of more digital or mobile training, but different training. Teachers who do receive training often express a wish for professional development, which focuses less on the technology itself and more on the pedagogy of its use. As stated in the UNESKO Mobile Learning Week Symposium Report: "Technology - and perhaps mobile learning in particular - requires re-conceptualizing the role of the teacher and models of pre- and in-service training" [10]. This project run by UNESKO in the city of Lahore, Pakistan, seeks to help students distribute educational content to students in disadvantage areas with the help of SMS texts, retain and strengthen their new literary skills, which are usually stunted if there's not constant practice.

When we talk about mobile learning apps, we mean learning that is done through portable devices as smartphones and tablets. In her article entitled "Challenges of teaching in the age of the Internet" Jennifer Fleming wrote that "teaching in the Internet age means we must teach tomorrow's skills today" [4]. She cited podcasts, blogs, iPods, and other technologies as teaching tools that she thinks need to be used in the classroom. Educators can learn how to take advantage of these and other innovative technologies through different professional development programs.

The key factor in the success of making productiveskill tasks is the way teachers organize them and how they respond to the student's work using mobile phones with downloaded educational applications. Educational apps are making thing easier for students to understand. Moreover, books are often found to be tiring and boring for learners while replacing them with colorful pages, meaningful information and moving animations can make learning fun to the core. 
Benefits of using mobile applications in teaching are as follows: 1) Enhanced interaction. Experts say that apps in education make learners more interactive and activate better engagement between parents and children. 2) New learning techniques. Technology in the guise of is helping those looking for some newness in the universe of learning. In addition to the feel of novelty, apps add an element of fun and involvement to the learning process. The games, puzzles or other challenging tasks, app learning stimulates the brain cells to actively metabolize the input releasing a new perspective. 3) Parent-teacher communication. The ideal concept of frequent parent-teacher interactions finds its space anytime and anywhere through the phone about the child's growth at school. 4) Online resources. The wealth of the online platform implicates its popularity among knowledge seekers. The reach of this platform makes it a favorite to those who can't afford full time courses in high schools or colleges. Mobile apps help them access a compendium of eBooks, pdfs and other online materials and the freedom to access it beyond the boundaries of time and space. 5) Entertainment. Due to studies $[1 ; 5]$, mobile apps promote entertainment. Learning is no more a passive activity; it's active with applications. Lessons transforming to games can change the face of education. Besides learners will enable a kind of interest in learning and no more boring home works and tough class lectures. 6) Availability 24/7. Mobile applications unlike school are available round the clock. No need to be worried about schedules. Anywhere can be a classroom. App learning is not time-bound learning, it's relaxed learning. Moreover, most of the apps promote child-friendly control. 7) Leisure hour's utilization. No responsible parents want their kids to get addicted to the phone. Too much Internet usage isn't a wise option for killing time. This is where mobile apps prove their worth. Mobile app learning is among the wisest choices of utilizing a free time actively. 8) Routine tasks. It's a relief to get all the tasks done with a few taps. Be it tasks like fee payment, other transactions that require us to stand in a queue for hours or the laborious job of marking attendance that drives teachers crazy with amount of paperwork having each day. All this drudgery has been put to an end simply by having apps in place. 9) Filling in the gaps. The advancement that schools have seen eliminated many glitches that prevailed in the education system. A major one is the lack of interaction between the teachers and the teachers. Phone apps and websites have been created to help reduce the gap not between the students and the educators but also among parents and the teachers. 10) Systematic learning activated. Mobile apps help in systematic learning. Apps are arranged in such a systematic way that it becomes possible for students to go with the flow without even realizing. 11) Portability. There are no restrictions for mobile phones. They can be constant companions of teachers, parents and students. Thereby, apps are available to learners all the time. Learning won't be confined to the classrooms only. 12) Instant updates. There are some phone apps, which stay updated about different learning events, timetables and other important information. They provide opportunities to interact with students throughout the life cycle, post-graduate students, colleagues, and alumni. 13) Track your students' progress. With some apps, you can track your students' pro- gress, which is one of the important things that every teacher wants to know. Along with the progress, you can visualize how each app helps your students improve their skills such as writing, speaking, listening. 14) Staying connected. Educational apps are the best way for learners to stay connected with their teachers. Though the way of learning through apps is entirely different from the traditional learning method, it adds to the entire process.

The first most commonly used model for future foreign language teacher training in new technologies is Content and Language Integrated Learning (CLIL). It involves a set of so-called $21^{\text {st }}$ century skills, which amongst other things include creativity and innovation, critical thinking and problem-solving, collaboration and team work, autonomy and flexibility, and lifelong learning, all bundled together with digital literacies. Many educators emphasize the importance of $21^{\text {st }}$ century skills for individuals' personal agency, helping them to lead fulfilling personal and social lives, and enabling them to participate as engaged teachers in national and international conversations $[2 ; 8]$. For educators, it is important to develop a critical mobile literacy because it offers a lens through which to focus on finding a balance among competing interests and help students open up spaces for growth amid the multiple discourses. New literacies and new skills don't only improve the chance of self-realization through economic opportunity but increase the richness of personal and social lives, and make it easier to acquire a 'voice' in local, national and international conversations [5].

A number of successful initiatives show that language, computer digital literacy and $21^{\text {st }}$ century skills can be taught simultaneously to great effect. The second most commonly used model for teacher training in new technologies, in our opinion, is Punya Mishra and Matthew Koehler's (2006) TPCK framework [7] (see Figure 1). Here, new technologies, mobile or otherwise, aren't treated as a separate field of knowledge, but as interlinked components such as technological knowledge (TK), pedagogical knowledge (PK), content knowledge (CK), pedagogical content knowledge (PCK), and technological pedagogical knowledge (TPK). According to the scientists, teachers remain content experts (who need a solid foundation a technological knowledge (TK) and ideally fluency in the language they're teaching) and pedagogical experts (who understand behaviorist, communicative and sociocultural approaches to language teaching and an associated kit of materials and activities).

Technological pedagogical content knowledge (TPCK)

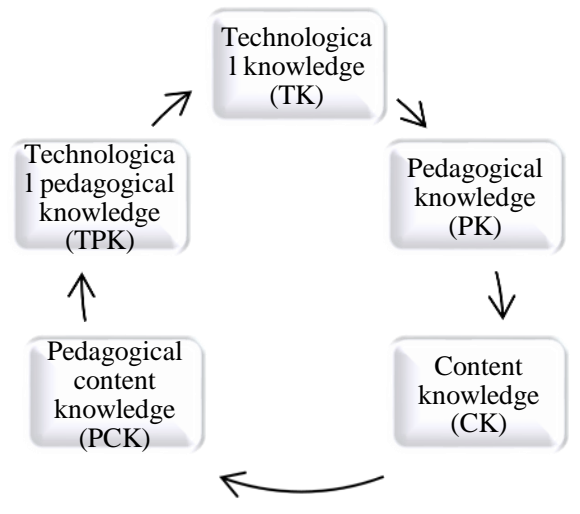

Figure 1. The TPCK framework. 
Technological knowledge (TK) serves to enhance teacher's content, pedagogical understandings, and digital options. Pedagogical knowledge $(P K)$ is needed to tailor teaching to the context, to recognize the differences appropriate for trainers and teachers to aim, to develop greater openness to the possibilities of interactive pedagogies, learner-centered classrooms, transformative uses of new tools, psychological comfort during the study. Content knowledge (CK) involves teachers becoming aware of the content they may teach (for instance, speaking, online reading or writing skills). Pedagogical content knowledge $(P C K)$ helps them organize the process of teaching (role-play, team work, projects, games, feedback, self-assessment, etc.). Developing technological pedagogical knowledge (TPK) involves teachers becoming aware of how digital technologies can complement their pedagogical strategies.

To be maximally effective, teachers need to be more than creators and curators, they need to become designers of learning experiences for their students. The value of seeing teaching as a design science is not restricted to the digital era, but learning design takes on an added peculiarity when education entails effectively and efficiently integrating pedagogy and technology as in the TPCK framework. Learning design is crucial to e-learning and to $\mathrm{m}$-learning. More over, the challenge of education is no longer about delivery of knowledge: it is about designing environments, tools and activities for learner to construct knowledge. In order for educators to effectively orchestrate learning within this study they need to perceive themselves, and indeed to be perceived by society, as technological and pedagogical designers.

At the same time, the spread of user-friendly software for creating learning materials has dramatically reduced entry levels. While this software is more about shaping details than designing the overall form of learning, it greatly expands the capacity of teachers with little code literacy to customise materials to better suit their pedagogical purposes and their students' learning needs.

Indeed, digital technologies may open the gates to transformation, whether teachers are ready or not - which is why 'the Trojan horse' metaphor has been applied to digital tools in general and mobile tools in particular. Some teachers use new technologies as best they can, trapping them within old pedagogical and organizational structures. But those who are open to the possibilities at the intersection of their TK, CK and PK may find their whole mindset starting to shift. As S. Dikkers (2011) notes, "learning to use technology well is a multi-year process and involves not only the development of teachers' technical skill, but also an evolution of their ideas about teaching and learning" [1]. This usually involves a shift away from transmission and behaviorist approaches towards more powerful and empowering teaching and learning, coupled with a shift away from old structures of classroom authority towards more collaborative relationships between teachers and students. Such changes are very much promoted by the affordances of mobile devices as observed in studies around the world [Dikkers (2011); Dudeney, Hockly, Pegrum (2013); Kolodko (2018)]. Notwithstanding the necessity to alter teaching to the context and recognize the differences between using a mobile device in the classroom, it may be appropriate for trainers and teachers to aim over time to develop greater openness to the possibilities of more interactive pedagogies, more learner-centred classrooms and more transformative uses of new tools, all of which are mutually reinforcing and whose promise is evident in projects from diverse contexts.

While numerous projects have focused on teaching students via mobile technologies, far fewer have focused on teaching teachers via the same tools [11]. Notable exceptions in the developed world include several projects funded under the UK Mobile Learning Network program where, for instance, trainee teachers used Skype on mobile phones to communicate with supervisors, or used video cameras to record their teaching for selfassessment [3].

There's also a need to find the most accessible digital interface, which is often a mobile phone screen, but may sometimes be a screen on a laptop or other mobile phone screen, but may sometimes be a screen on a laptop or other device. Naturally, a given mobile device doesn't only supplement other digital tools but also analogue tools, which is important in the developing and developed world. A combined digital and analogue approach is seen for instance in the complementary use of phones and books in Ukraine, Australia, UK, Turkey, China, Indonesia, Pakistan, Cambodia, Sudan, Libya, etc. In a recent survey with our students in a course on new technologies and language learning, we found that three mobile technologies were in regular use - the phone, the tablet and the laptop computer. Each of these technologies is 'mobile' in different ways, of course. Further, we found two or more of these technologies were used regularly for particular tasks, with varying profiles. For each group, reading the news was primarily conducted via the laptop $(90 \%)$, with the phone a strong second (59\%). With reading a book, the profile changed, with the laptop (59\%) and the phone (31\%) representing the newer technologies and hard copy book (62\%); of course, the traditional book is a good example of a mobile technology and it is still the leading modality. When accessing online dictionaries for language learning, again the laptop (92\%), and the phone $(79 \%)$ dominated, while traditional paper-based dictionary use had almost disappeared. These results represent just one example. The contribution of each mobile technology shifts over time, giving each individual user a particular profile.

The spread of mobile technology types now available on the market is intriguing. In some ways, it is as if technology designers are experimenting with the customer as they invite us to implicitly evaluate designs through our product choices. Variables in play include screen size, virtual or material keyboards, touchscreens, and so forth. Whatever the final result, the user is empowered with the range of technologies they have at their disposal. Technology is meant to be emancipatory; to do what others have formerly done. In language learning, our research is showing personal mobile technologies are being used increasingly inside the classroom as well as, for example in consulting a mobile phone dictionary to look up a new word when it arises in class. 
Now let's investigate the troubles with mobile technologies. Mobile hardware, networks and software were generally not designed with education in mind. When they are repurposed, their limitations and risks are bound to become evident. Mobile literacy must surely include an awareness and understanding of all the limitations and risks. According to Global System for Mobile Communications Association (2010) they are as follows: 1) The hardware confronts teachers and learners with limited screen sizes, especially on feature phones which are a challenge for extended reading; 2) limited input options which are a challenge for composing extended text and on smart devices, for multimodal creation and manipulation; 3) limited speed and capacity which is a challenge for working with multimodal and other apps; 4) limited storage which is a challenge for saving large amounts of multimedia material; 5) limited export options which are a challenge for sharing larger documents and artifacts; 6) limited battery life which is a minor challenge in the developed world; 7) limited environmental adaptability to conditions like sunshine and rain; 8) limited strength which is a considerable challenge in harsh conditions. Many of these issues both reflect and contribute to broader design limitations: mobile devices, including smart devices or simple kinds of phones. As a result, iPads and other smart devices are often viewed as a supplement to more generative devices like laptops especially at higher educational levels.

Much is to be said about the need for adequate technological and pedagogical support for teachers and learners as they integrate new tools into their teaching and learning processes. It's vital that educators start to think criti- cally and help their students to do the same - not just about hardware, connectivity and software, nor even just about the pedagogies they support, but about the broader cultural, social, political and economic ecologies in which they're embedded.

A given mobile device doesn't only supplement other digital tools but also analogue tools, which is important in the developing world - and also in evidence in the developed world. A combined digital and analogue approach is seen for instance in the complementary use of phones in Ukraine.

Conclusions. As development level increase, so do the technological possibilities along with the associated mobile literacy demands on teachers. With appropriate technology at their disposal, effective teachers can and should become creators and curators of learning materials for their students. As creators teachers need experience in the productive aspects of multiple mobile literacy. As curators teachers must add to their repertoire the information language skills to identify, evaluate and catalogue relevant content, complemented by the network literacy skills to leverage online connections to help discover as well as scatter this content. It will also allow them to mentor their students in developing the very same digital literacies as they learn to become specialists of digital content within a creation of a mobile learning paradigm.

The study conducted does not solve all the above mentioned problems. The perspective of the further research is to outline the students' stimuli for their self-education and teachers' creativity in mobile adaptation to changes in innovative environment.

\section{REFERENCES}

1. Dikkers, S. (2011). Dewey Buys a Smartphone. Mobile Media Learning: Amazing Uses of Mobile Devices for Learning. Pittsburgh, PA: ETC Press.

2. Dudeney, G., Hockly, N., Pegrum, M. (2013). Digital Literacies. Harlow, Essex: Pearson.

3. Dykes, G. \& Renfrew Knight, H. (2012). Mobile Learning for Teachers in Europe: Exploring the Potential of Mobile Technologies to Support Teachers and Improve Practice. Paris: UNESCO.

http://unesdoc.unesco.org/images/0021/002161/21617E.pdf

4. Fleming, J. (1998). Challenges of Teaching in the Age of the Internet.

5. Kolodko T. Continuing Professional Development of English Language Teachers: Focus on English Teaching Framework // Danish Scientific Journal. - Denmark. - 2018, № 19, Vol. 2. - P. 57-60.

6. Leadbeater, C. (2008). We-think. London: Profile Books.
7. Mishra, P. \& Koehler, M.J. (2006). Technological Pedagogical Content Knowledge: A Framework for Teacher Knowledge. Teachers College Record, 108(6), 1017-1054.

8. Pegrum, M. (2009). From Blogs to Bombs. The Future of Digital Technologies in Education. Crawley, WA: UWA Publishing.

9. O'Reilly, T. \& Battelle, J. (2009). Web Squared: Web 2.0 Five Years On. Sebastopol, CA: O'Reilly Media. http://assets.en.oreilly.com/1/event/28/web2009_websquaredwhitepaper.pdf

10. UNESKO Mobile Learning Week Symposium Report. http://www.unesko.org/new/fileadmin/MULTIMEDIA/HQ/E D/ICT/pdf/MLW_Report.pdf

11. Vosloo, S. (2012). Mobile Learning and Policies: Key Issues to Consider. Paris: UNESCO http://unesdoc.unesco.org/images/0021/002176/217638E.pdf 